\title{
Evaluation of litter material and ventilation systems on poultry production: II. thermal comfort
}

\author{
Paulo Giovanni de Abreu ${ }^{1}$, Valéria Maria Nascimento Abreu ${ }^{1}$, Arlei Coldebella ${ }^{1}$, Fátima \\ Regina Ferreira Jaenisch ${ }^{1}$, Doralice Pedroso de Paiva ${ }^{1}$
}

${ }^{1}$ Embrapa Suínos e Aves, Br 153, Km 110, Caixa Postal 21, 89700-000, Concórdia, Santa Catarina, Brasil.

ABSTRACT - The objective of this study was to evaluate environmental thermal conditions in broiler houses with two different ventilation systems and two different litter materials. The experiment was carried out in four $12 \mathrm{~m} \times 10 \mathrm{~m}$ broiler houses, internally divided in 4 boxes/poultry house, with 200 birds/pen for four consecutive flocks, each one with a duration of 42 days with 15 days of downtime between flocks. Treatments tested were two ventilation systems (stationary or oscillating fans), and two types of litter materials (soybean straw or rice husks). It was collected in the center of each pen and in the external enviroment, dry and wet bulb temperatures, black globe temperature, and air velocity. These data were collected at 3-hour intervals from 8:00 a.m. to 6:00 p.m. at the fourth, fifth and sixth week age of the bird. Based on the data collected at each time, wet and globe temperature index (WBGT) and radiant heat load (RHL) were determined. Litter temperature reaings were also performed by using an infrared thermometer. Effects of flock, ventilation, week, hour and the interactions among factors on the studied variables were evaluated in the analysis of the internal thermal environment by using the theory of mixed models for repeated measures. Ventilation provided by stationary and oscilating fans had equal behavior and it did not affect the studied variable. However, both ventilation systems are sufficient to soften internal thermal conditions in the broiler house in relation to the external environment. Relative humidity of the air is higher when rice husks is used as litter material.

Key Words: broilers, oscillating ventilation, rice husks, soybean straw, stationary ventilation

\section{Avaliação de materiais de cama e sistemas de ventilação na criação de aves: II. conforto térmico}

\begin{abstract}
RESUMO - Este trabalho foi conduzido com o objetivo de avaliar as condições térmicas ambientais em aviários com dois sistemas de ventilação e dois materiais de cama. O experimento foi realizado em quatro aviários de $12 \mathrm{~m} \times 10 \mathrm{~m}$ para frangos de corte, divididos internamente em 4 boxes/aviário, com 200 aves/boxe por quatro lotes consecutivos, cada um com duração de 42 dias e com intervalo de vazio sanitário de 15 dias entre lotes. Os tratamentos testados foram dois sistemas de ventilação (fixo e oscilante) e dois tipos de material de cama (palhada de soja e casca de arroz). Foram coletadas no centro de cada boxe e no ambiente externo a temperatura de bulbo seco e úmido, a temperatura de globo negro e a velocidade do ar. Esses dados foram coletados em intervalos de três horas, de 8 às 18 horas, na quarta, quinta e sexta semanas de vida das aves. Com base nos dados coletados em cada horário, foram determinados o índice de temperatura de globo e umidade (WBGT) e a carga térmica radiante (RHL). Também foram feitas leituras da temperatura da cama por meio de termômetro infravermelho. Na análise dos dados de ambiente térmico interno, foram avaliados os efeitos de lote, ventilação, semana, hora e as interações dos fatores sobre as variáveis avaliadas, utilizando-se a teoria de modelos mistos para medidas repetidas. A ventilação proporcionada por ventiladores fixos e oscilantes comportou-se igualmente e não teve efeito sobre as variáveis estudadas. No entanto, as duas formas de ventilação são suficientes para amenizar as condições térmicas internas do aviário em relação ao ambiente externo. A umidade relativa do ar é maior quando se utiliza a casca de arroz como material para cama.
\end{abstract}

Palavras-chave: casca de arroz, frango de corte, palhada de soja, ventilação estacionária, ventilação fixa

\section{Introduction}

Optimal productivity is improving the use of energy for growth while maintaining birds in their comfortable temperature range with no need to waste energy to compensate for cold or hot temperatures. There are many ways to maintain comfort temperatures in the poultry house, and one of them is ventilation. Artificial ventilation is provided by fans, and it is used whenever natural ventilation conditions do not provide adequate air movement or temperature reduction. The amount of air that the ventilation system needs to introduce or to remove from the broiler

Received March 17, 2010 and accepted December 21, 2010.

Corresponding author: pabeu@cnpsa.embrapa.br 
house depends on the weather conditions, internal poultry house environment conditions, and bird density and age (Abreu \& Abreu, 2000).

Under hot conditions, when temperatures are high, air movement is essential for the improvement of environmental conditions, and it acts in two main forms. When air velocity increases as environmental temperatures are below body temperatures, heat is dissipated by convection, and also favors evaporative cooling at any environmental temperature, and in addition, air is renewed around the birds, replacing the existing air by cooler and drier air. This promotes the dissipation of bird heat to the environment and also increases oxygen levels and reduces carbonic gas and ammonia concentrations in the air (Baêta et al., 2001).

Litter has never been a subject of extensive studies or considered a priority in large poultry company. However, due to the increasing lack of good litter material, more attention has been given to proper litter management, litter reuse, and to the search for new litter materials. In this context, the use of crop residues as poultry litter material seems to be promising.

Therefore, the present study was carried out to evaluate environmental temperature in broiler houses as influenced by two ventilation systems (stationary and oscillating) and two litter materials (soybean straw and rice husks).

\section{Material and Methods}

The experiment was carried out at the experimental field of Suruvi, which belongs to Embrapa Suínos and Aves, Concórdia, Santa Catarina, Brazil. Four $12 \mathrm{~m} \times 10 \mathrm{~m}$ broiler houses were internally divided in four pens each (total of 16 pens), at a density of 200 birds/pen $\left(28 \mathrm{~kg}\right.$ meat $\left./ \mathrm{m}^{2}\right)$, totaling 3.200 birds/flock. Four consecutive flocks were followed. Each flock was reared until 42 days of age, and an interval between flocks (downtime) of 15 days was applied.

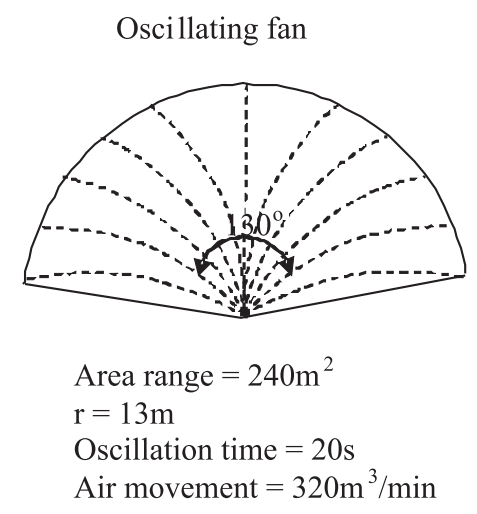

Two ventilation systems (stationary or oscillating), reaching a distance of $10 \mathrm{~m}$, and two litter materials (soybean straw or rice husks) were evaluated. Rice husks and ventilation system using stationary fans are considered as standards as they are commonly used in broiler production. Fans were activated by a thermostat when the environmental temperature reached $25^{\circ} \mathrm{C}$, and they were equipped with a potentiometer and speed regulator matching the broiler house size (Figure 1). Treatments were distributed as follows (Figure 2): house 1 - stationary ventilation system, pens 2 and 3 with soybean straw; pens 1 and 4 with rice husks; house 2 - oscillating ventilation system, pens 2 and 3 with soybean straw; pens 1 and 4 with rice husks; house 3 oscillating ventilation system, pens 1 and 4 with soybean straw; pens 2 and 3 with rice husks; house 4 - stationary ventilation system, pens 1 and 4 with soybean straw; pens 2 and 3 with rice husks.

The following psychrometric parameters were recorded at the center of each pen and in the external environment: dry- and wet-bulb temperature, black globe temperature, and air velocity. Temperatures were collected by using copper-constant thermocouples connected to a potentiometer and a 20-channel selecting key. The wet bulb thermometer was characterized by holding a cotton wick attached to the thermocouple terminal to the mercury bulb and immersing it in a flask with distilled water. Black globe temperature was collected by placing thermocouples inside a hollow $15 \mathrm{~cm}$ diameter PVC sphere painted with black mat spray paint. Air velocity was recorded using a digital anemometer $\left(\right.$ Pacer $^{\circledR}$ Model DA40V), with a resolution of $0.01 \mathrm{~m} / \mathrm{s}$. Data were collected every three hours, from 8:00 a.m. to 6:00 p.m. when broilers were 4, 5, and 6 weeks of age. Based on the data collected at each time, wet and globe temperature index (WBGT) and radiant heat load (RHL) were determined. Litter temperature was also measured by using an infrared thermometer Raytec ${ }^{\circledR}$ at five different spots in each pen

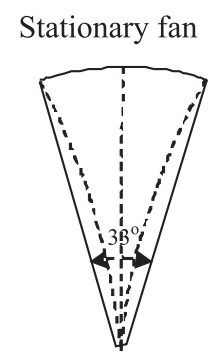

Area range $=134.40 \mathrm{~m}^{2}$

$\mathrm{r}=20 \mathrm{~m}$

Oscillation time $=20 \mathrm{~s}$

Air movement $=320 \mathrm{~m}^{3} / \mathrm{min}$

Figure 1 - Fan traits. 
(two near the lateral pen wall, two near the central aisle, and at the geometrical center of the pen) every three hours, from 8:00 a.m. to 6:00 p.m. when broilers were 6 weeks of age. Based on the average data in each spot, isothermal maps of litter temperature using the kriging method of the SURFER software program were built.

Internal thermal environmental parameters were evaluated as to the effects of flock, ventilation, litter, week, hour, and the interactions among the last four factors by using mixed models for repeated measures and 19 variance and covariance matrix structures by applying PROC MIXED procedure of SAS statistical package (SAS, 2003), according to Xavier (2000). The structure used for analysis was chosen based on the lowest value of the Akaike Information Criterion (AIC). The estimation method was that of restricted maximum likelihood. The effect of hour was detailed using orthogonal polynomial analysis up to the polynomial of the third degree. For the external environment, parameter means were calculated as a function of hour and week in order to compare the internal with the external thermal environment.

\section{Results and Discussion}

The main effects of flock, week and hour were significant $(\mathrm{p}<0.05)$ for all evaluated parameters. Litter material significantly influenced $(\mathrm{p}<0.05)$ only air relative humidity, whereas ventilation system did not affect any of the parameters. The hour $\times$ week interaction significantly affected all parameters, whereas the effect of the ventilation $\times$ hour interaction was significant only for air temperature and WBGT (Table 1).

There was no effect of the ventilation system, provided by stationary or oscillating fans on the studied parameters
(Figure 2). However, both ventilation systems were adequate to ameliorate internal thermal conditions as compared to the external environment, because the temperature inside the broiler house was always maintained below $25^{\circ} \mathrm{C}$, which was the temperature set in the thermostat, despite external temperature having reached, at determined times, more than $29^{\circ} \mathrm{C}$. Wet and globe temperature index, and air relative humidity ranges inside the broiler house were also mitigated by both ventilation systems when compared to the external environment. This result is consistent with the findings of Sevegnani et al. (2001), who demonstrated that higher air velocity on the body surface of broilers promotes convective sensitive heat losses to the environment, and effectively reduces broiler heat stress. According to Ecim-Djuric \&Topisirovic (2010), incoming air velocity depends on wind velocity and inlet angle in the poultry house. Very high values of air velocity do not promote healthy conditions inside the poultry house. In order to ensure good fan performance, their belts must be submitted to constant maintenance, as dust and corrosion may impose extra resistance, reducing air flow (Casey et al., 2008). According to Casey et al. (2008), fans are essential components of the ventilation system for birds reared indoors, and they are used to promote air flow and renewal. The fresh air carried by fans supplies birds with oxygen and removes heat, humidity, and air contaminants from poultry houses. The amount of air that the ventilation system needs to introduce or to remove from the poultry house depends on the weather conditions, internal environment, and bird age (Abreu \& Abreu, 2000). Moraes (2002) observed that after 21 days of age, broilers suffered heat stress between 12:00 p.m. and 4:00 p.m. when evaluated by WBGT values, which were higher than 76 . In the present study, in the internal

Table 1 - Summary of P-values of the analysis of variance (ANOVA) for air temperature, wet bulb globe temperature (WBGT), radiant heat load, air relative humidity, litter temperature and their interactions

\begin{tabular}{|c|c|c|c|c|c|}
\hline Causes of variation & Air temperature & WBGT & Radiant heat load & Air relative humidity & Litter temperature \\
\hline Flock & $<0.0001$ & $<0.0001$ & $<0.0001$ & $<0.0001$ & $<0.0001$ \\
\hline Litter & 0.9588 & 0.7747 & 0.7824 & 0.0210 & 0.8625 \\
\hline Ventilation & 0.8161 & 0.9372 & 0.7622 & 0.8928 & 0.9826 \\
\hline Ventilation $\times$ litter & 0.9853 & 0.9227 & 0.5614 & 0.1476 & 0.9027 \\
\hline Week & $<0.0001$ & $<0.0001$ & $<0.0001$ & 0.2759 & $<0.0001$ \\
\hline Ventilation $\times$ week & 0.8379 & 0.7251 & 0.7174 & 0.8089 & 0.9290 \\
\hline Litter $\times$ week & 0.9872 & 0.9923 & 0.9744 & 0.9300 & 0.9616 \\
\hline Ventilation $\times$ litter $\times$ week & 0.9833 & 0.9947 & 0.9813 & 0.8244 & 0.9968 \\
\hline Hour & $<0.0001$ & $<0.0001$ & $<0.0001$ & $<0.0001$ & $<0.0001$ \\
\hline Ventilation $\times$ hour & 0.0211 & 0.0526 & 0.1938 & 0.9408 & 0.4040 \\
\hline Litter $\times$ hour & 0.9998 & 0.9436 & 0.7443 & 0.1739 & 0.4929 \\
\hline Ventilation $\times$ litter $\times$ hour & 0.9787 & 0.9895 & 0.5885 & 0.1545 & 0.8950 \\
\hline Hour $\times$ week & 0.0098 & 0.0120 & 0.0023 & 0.0013 & 0.0463 \\
\hline Ventilation $\times$ hour $\times$ week & 0.5552 & 0.8865 & 0.9334 & 0.2365 & 0.9271 \\
\hline Litter $\times$ hour $\times$ week & 0.9997 & 0.9807 & 0.9955 & 0.4640 & 0.9962 \\
\hline Ventilation $\times$ litter $\times$ hour $\times$ week & 0.9994 & 0.9998 & 0.9979 & 0.5673 & 0.9987 \\
\hline
\end{tabular}

Non-structured variance and covariance matrix structures were used. 
environment of broiler houses with both stationary and oscillating ventilation systems, WBGT values did not reach 76 during the entire experimental period, indicating that birds remained comfortable. According to Medeiros et al. (2005), in environments considered comfortable (WBGT between 69 and 77), broilers present better performance. In a study evaluating radiant heat load, Moraes (2002) used the value of $450 \mathrm{~W} \cdot \mathrm{m}^{-2}$ as the upper thermal comfort limit of adult broilers. In the present study, both ventilation systems determined values close to each stress ( 455 and $453 \mathrm{~W} \cdot \mathrm{m}^{-2}$ )
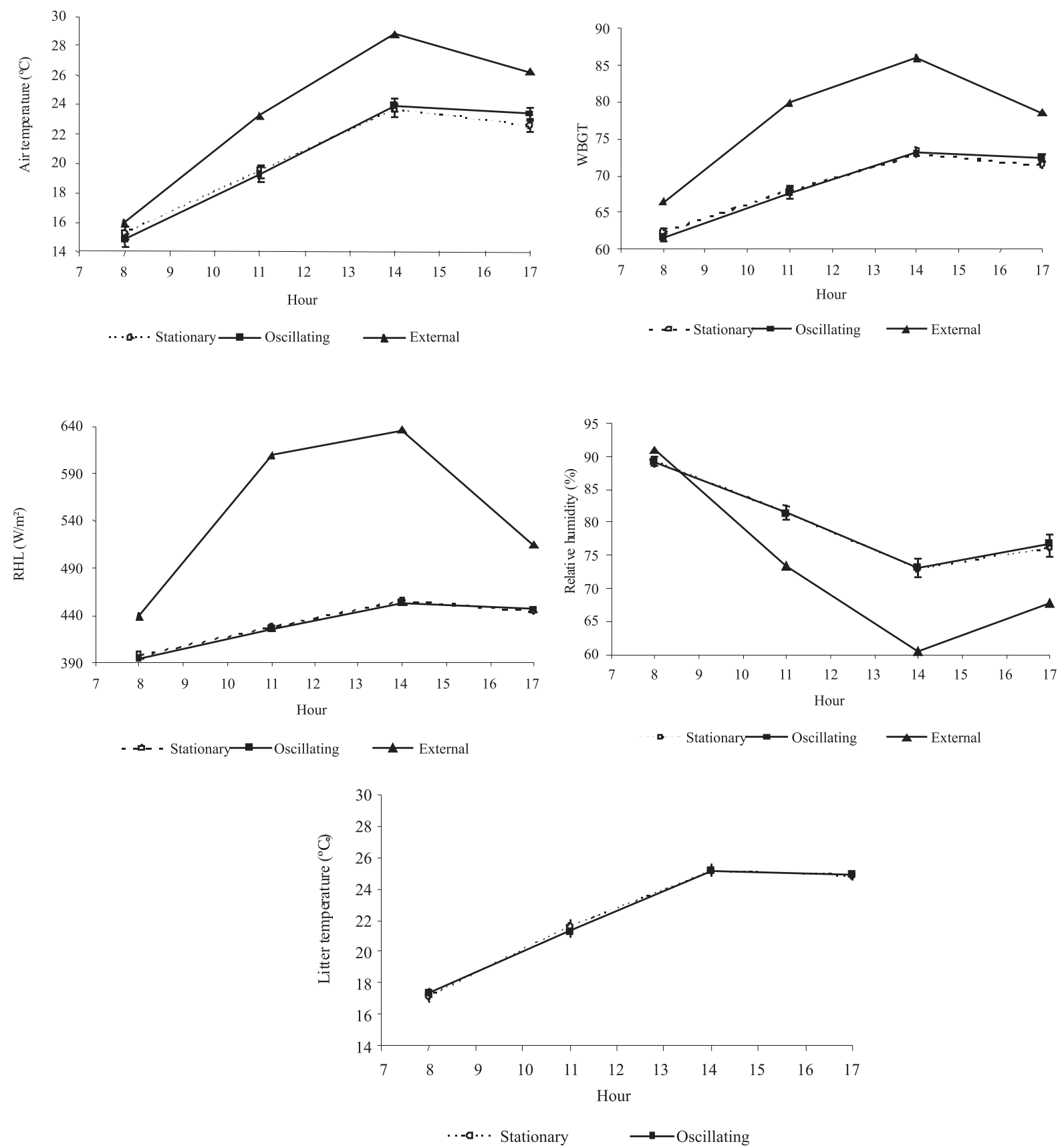

Figure 2 - Air temperature, wet bulb globe temperature (WBGT), radiant heat load (RHL), and air relative humidity inside broiler houses with two different ventilation systems.

R. Bras. Zootec., v.40, n.6, p.1356-1363, 2011

at 2:00 p.m. Air relative humidity had a cyclic behavior, opposite to environmental temperature. This behavior was expected because high temperatures are usually associated with low air relative humidity. During the period from 11:00 a.m. and 5:00 p.m., ventilation system efficiently maintained air relative humidity within the recommended range, but from 8:00 a.m. to 11:00 a.m., air relative humidity was higher than the recommendations in both ventilation systems, which was caused by the high air relative humidity in the external environment. Litter temperature had the same cyclic

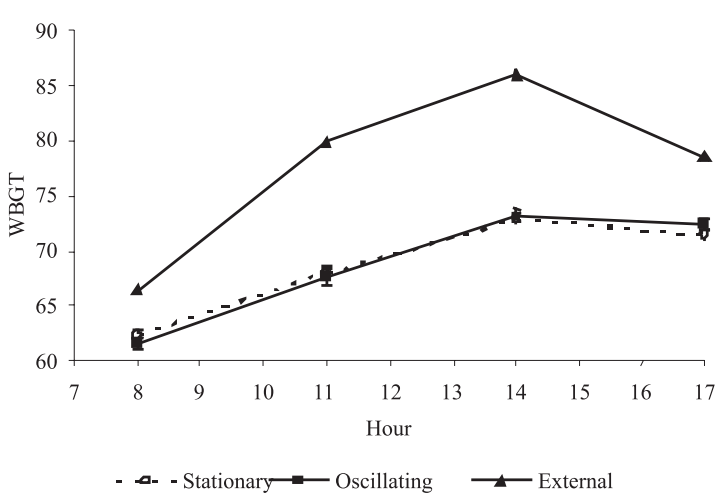


behavior as air temperature in both ventilation systems, reaching a maximum value of $25^{\circ} \mathrm{C}$ at 2:00 p.m.

According to Abreu \& Abreu (2001), optimal air temperature values are between $23^{\circ} \mathrm{C}$ and $26^{\circ} \mathrm{C} ; 20^{\circ} \mathrm{C}$ and $23^{\circ} \mathrm{C}$; and $20^{\circ} \mathrm{C}$ for broilers at 4 and 5 weeks of age, respectively. On the other hand, the recommended air relative humidity is 60 to $70 \%$, regardless of bird age. In the present study, air relative humidity remained higher than the recommendations for broiler production in all studied weeks, times, and litter materials (Figure 3). Tinôco et al. (2001) studied the influence of two ventilation systems (fans placed in longitudinal or transversal directions) associated to internal fogging and roof spraying on the air relative humidity of broiler houses, and found higher values when the transversal system was used.

Oliveira et al. (2006) found that high air temperatures impaired the performance and prime cuts yield of broilers from 1 to 49 days of age, and that this effect was intensified as air relative humidity increased. Furtado et al. (2003) analyzed the thermal comfort in poultry houses using different conditioning systems, and concluded that black globe temperature, humidity, and radiation heat load presented, at the hottest times in the day, values higher than those considered optimal for broilers, whereas air relative humidity remained within the optimal range. Oliveira et al. (2000) tested the effect of roof insulation on the performance of broilers housed at different densities and verified that the environment with insulation presented high air relative humidity during most of the day, and that insulation may hinder environmental humidity loss. On the other hand, in this study, the comparison between the internal (inside the broiler house) environment and the external conditions showed that, except for 8:00 a.m. there was a $4-6^{\circ} \mathrm{C}$ temperature difference at the other evaluated hours, making the internal environment more favorable to production.

Wet and globe temperature index values ranged from 61 to 71, depending on time, week, and litter material. According to Teixeira (1983), WBGT from 65 to 77 are compatible with broiler production. Therefore, in the present study, these values were lower than the recommendations only at 8:00 a.m. At the other times, during the three evaluated weeks and for both litter materials, WBGT values indicated that birds were in thermal comfort.

Heat load inside the broiler house did not show much variation, and the results were more favorable to the birds when compared to the external environment. When rice husks litter was used, higher air relative humidity values were detected (Figure 3). Controlling air and litter humidity is important to reduce pathogens, ammonia, and parasite, for example coccidia, in the poultry house environment (Soliman et al., 2009). Oliveira et al. (2002) did not find significant differences in breast blisters as a function of bird density ( $10 \mathrm{birds} / \mathrm{m}^{2}$ or $14 \mathrm{birds} / \mathrm{m}^{2}$ ), litter material (wood shavings or saw dust) or by their interaction, as this part of the broiler body is not in permanent contact with the litter, and therefore it is no influenced by litter humidity.

Litter temperature presented the same behavior as air temperature, as expected, with a linear correlation of 0.95 . At all evaluated times, litter temperature was $2^{\circ} \mathrm{C}$ to $3^{\circ} \mathrm{C}$ higher than air temperature, in average. It must be noted that litter temperature was not affected by the used material, that is, despite of using soybean straw or rice husks, litter temperature remained similar (Figure 3). According to Bessei (2006), temperature measured at $5 \mathrm{~cm}$ below litter surface was $23.5^{\circ} \mathrm{C}$ and $31.3^{\circ} \mathrm{C}$ athousing densities of 19 and $40 \mathrm{~kg} / \mathrm{m}^{2}$, respectively, whereas air temperature $1 \mathrm{~m}$ above litter surface was $22^{\circ} \mathrm{C}$, indicating that litter temperatures were $1.5^{\circ} \mathrm{C}$ and $9.3^{\circ} \mathrm{C}$ higher than the environmental temperature. The higher litter temperature at higher bird densities may be explained by different effects. As bird density increases, nitrogen and humidity levels increase in the litter, allowing higher microbial activity and the heat transference from the litter surface to the environmental air is prevented when the litter surface area is covered by birds, particularly as birds reach market weight.

Isolines indicate areas where litter temperature is the same, that is, they map the distribution of temperature on the entire litter surface. Litter temperature was stratified, with afternoon isolines presenting higher values than those obtained in the morning (Figure 4). Tavares et al. (2008), on the other hand, found that litter temperatures during brooding are not uniform in the brooding area, with higher temperatures in the east side of the building, because temperatures were collected in the morning, when sun incidence is higher. Conduction is one of manner which birds exchange heat with the environment (Abreu \& Abreu, 2004) and in order to be efficient, litter temperature must be lower than body temperature. Therefore, the possibility of predicting litter temperature in the entire broiler house will allow establishing actions to maintain temperatures within the comfort zone of the birds. This requires geostatistics techniques to predict values of the desired parameters in non-observed locations, that is, by using spatial interpolation, it allows knowing the parameter for an entire region. Franciscon et al. (2008) demonstrated that there is spatial dependence among litter temperature spots during brooding. Spatial interpolation showed that litter temperature in the brooding area was not uniformly distributed to the entire house area, and it was below the $23^{\circ} \mathrm{C}$ recommended for broilers at three weeks of age. Those authors recommended 

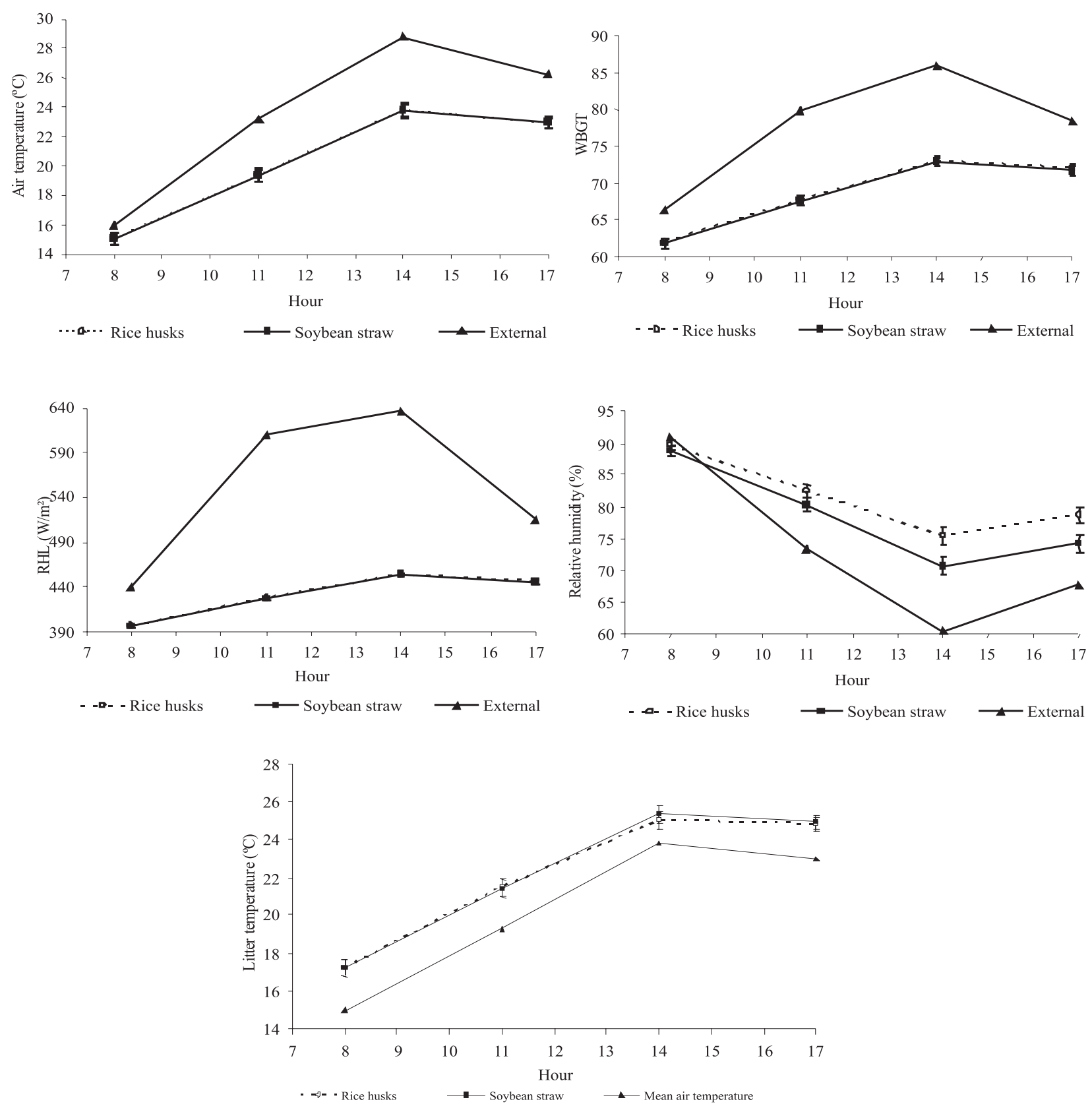

Figure 3 - Air temperature, wet bulb globe temperature (WBGT), radiant heat load (RHL), and air relative humidity inside broiler houses with two different litter materials.

that, in order to have uniform distribution of litter temperature, house insulation should be improved. Tavares et al. (2008) also found that litter temperature in the brooding area was not uniform and below the recommendations of $23^{\circ} \mathrm{C}$ for broilers at three weeks of age.

In the present study, litter temperature distribution was only uniform with soybean straw in the afternoon and using stationary ventilation system. Maximum litter value obtained in the morning was approximately $22^{\circ} \mathrm{C}$ in both types of litter material and both ventilation systems. In the afternoon, this value was around $27-28^{\circ} \mathrm{C}$. When birds are at six weeks of age, the main concern is with the heat stress, which usually happens in the afternoon. Therefore, in the present study, it was observed that the litter temperature in both ventilation systems contributed to air temperature increase. The highest litter temperature values were obtained near the north side wall of the house (Figure 4). Both ventilation systems and litter materials presented the same behavior. 


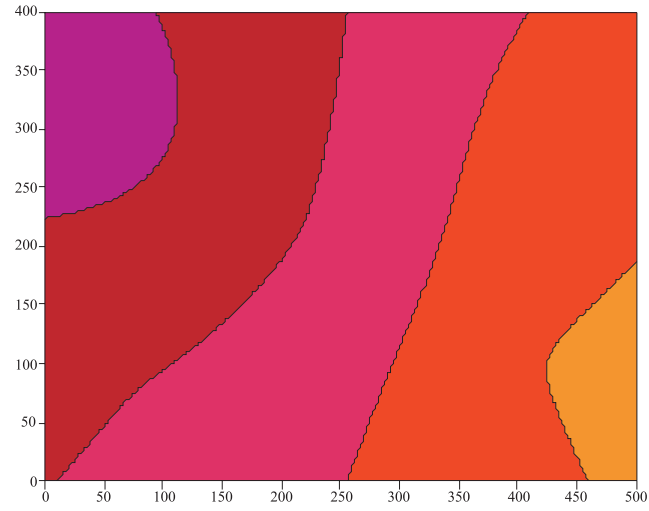

Stationary 6 - Rice husks (morning)

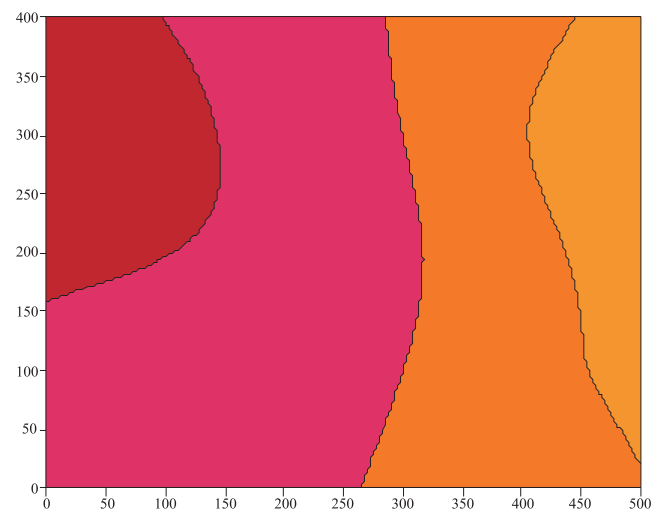

Stationary 6 - Soybean straw (morning)

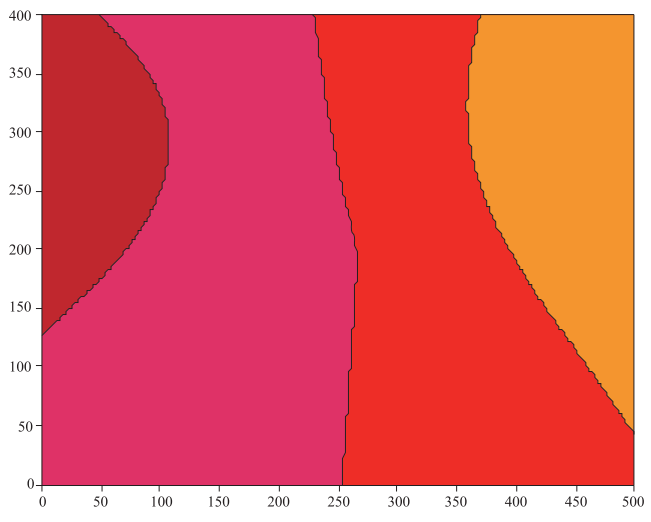

Oscillating 6 - Rice husks (morning)

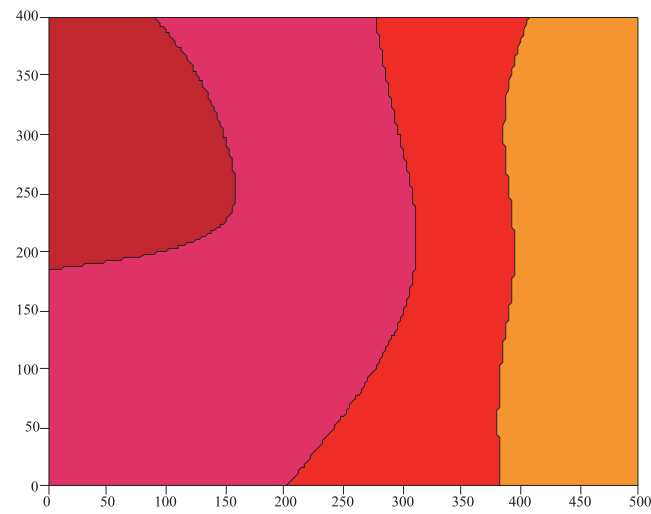

Oscillating 6 - Soybean straw (morning)
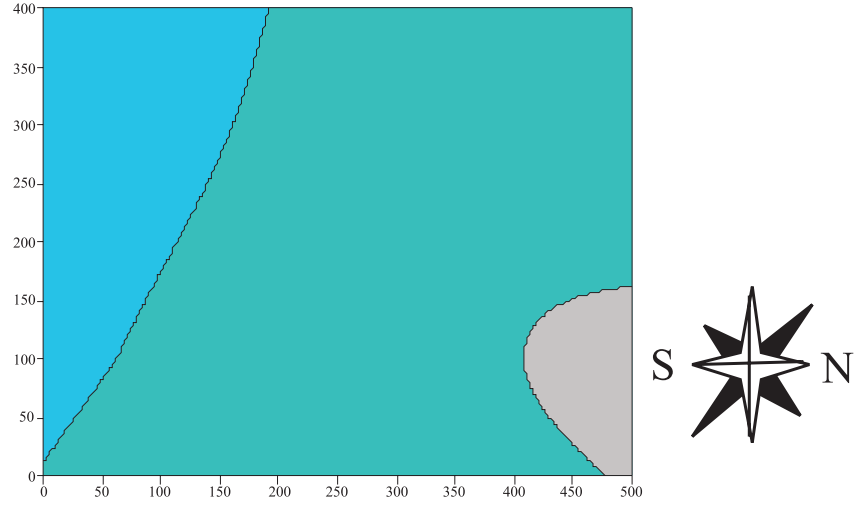

Stationary 6 - Rice husks (afternoon)

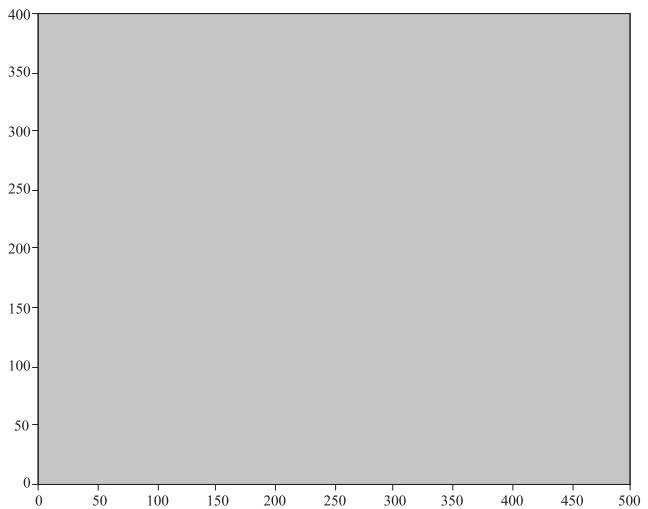

${ }^{\circ} \mathrm{C}$

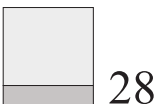

28

27.5

27

26.5

26

Stationary 6 - Soybean straw (afternoon)

25.5

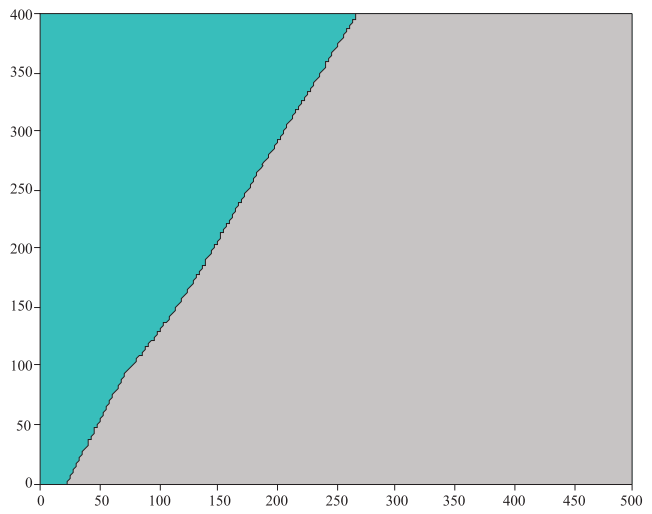

25

24.5

24

23.5

23

22.5

22

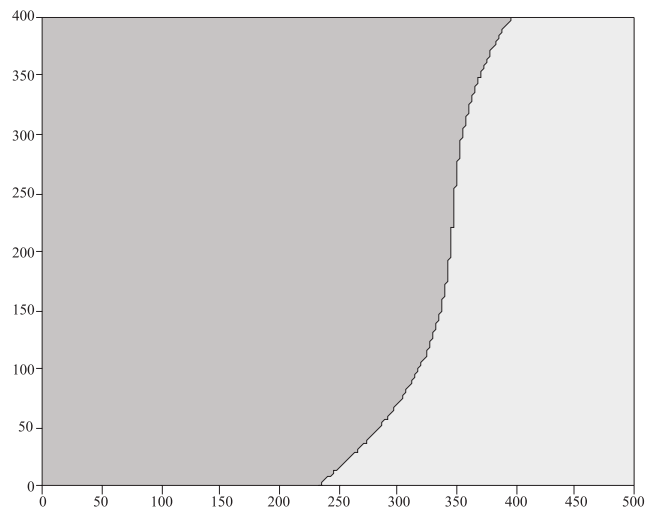

21.5

21

20.5

20

Figure 4 - Maps with temperature isolines of the litter of birds at six weeks of age according to ventilation system (oscillating and stationary) and litter type (soybean straw and rice husks) in the morning and in the afternoon. 


\section{Conclusions}

Ventilation provided by stationary and oscillating fans presents the same behavior and does not influence the evaluated environmental parameters. However, both ventilation systems efficiently improve thermal conditions inside the poultry house relative to the external environment. Air relative humidity is higher when rice husks are used as litter material. Solar radiation directly affects litter temperature. Litter temperature values obtained in the afternoon contribute to heat stress of birds. The use of insulation and of an efficient environmental control system, as well as better litter management are recommended to reduce the influence of litter temperature on the thermal environment of broiler houses.

\section{Acknowledgements}

The authors thank Fundação de Apoio à Pesquisa de Santa Catarina - FAPESC, for funding this study, Unifrango Agroindustrial de Alimentos Ltda., in the person of the farmer Mr. Arsênio for supplying the litter material, and Roster Ind. e Com. Ltda for lending the fans.

\section{References}

ABREU, P.G.; ABREU, V.M.N. Ventilação na avicultura de corte. Concórdia: Embrapa Suínos e Aves, 2000. 50p. (Documentos, 63).

ABREU P.G.; ABREU, V.M.N. Conforto térmico para aves. Concórdia: Embrapa Suínos e Aves, 2004. 5p. (Comunicado Técnico, 365).

ABREU, V.M.N.; ABREU, P.G. Diagnóstico bioclimático para produção de aves no Oeste Paranaense. In: CONGRESSO BRASILEIRO DE ENGENHARIA AGRÍCOLA, 30., 2001. Anais... Foz do Iguaçu: CONBEA, 2001. (CD-ROM).

BAÊTA, F.C.; FERREIRA, J.H.; MORAES I.F. et al. Desempenho da ventilação forçada no interior de galpões de corte, em função do posicionamento dos ventiladores e orientação do fluxo de ar, no verão. In: CONGRESSO BRASILEIRO DE ENGENHARIA AGRÍCOLA, 30., 2001. Anais... Foz do Iguaçu: CONBEA, 2001. (CD-ROM).

BESSEI, W. Welfare of broilers: a review. World's Poultry Science Journal, v.62, n.3, p.455-466, 2006.

CASEY, K.D.; GATES, R.S.; WHEELER, E.F. et al. On-farm ventilation fan performance evaluations and implications. The Journal of Applied Poultry Research, v.17, p.283-295, 2008.

ECIM-DJURIC, O.; TOPISIROVIC, G. Energy efficiency optimization of combined ventilation systems in livestock buildings 2010 . Energy and Buildings, v.42, p.1165-1171, 2010.
FRANCISCON L.; ABREU, P.G.; COLDEBELLA, A. et al. Análise geoestatística para modelagem da temperatura da cama de um aviário de frango de corte comercial. In: SIMPÓSIO NACIONAL DE PROBABILIDADE E ESTATISTICA, 18., 2008, Estância de São Pedro. Anais... Estância de São Pedro: SINAPE, 2008. (CD-ROM).

FURTADO, D.A.; AZEVEDO, P.V.; TINÔCO, I.F.F. Análise do conforto térmico em galpões avícolas com diferentes sistemas de acondicionamento, 2003. Revista Brasileira de Engenharia Agrícola e Ambiental, v.7, n.3, p.559-564, 2003.

MEDEIROS, C.M.; BAÊTA, F.C.; OLIVEIRA, R.F.M. et al. Efeitos da temperatura, umidade relativa e velocidade do ar em frangos de corte. Engenharia na Agricultura, v.13, n.4, p.277-286, 2005.

MORAES, S.R.P. Caracterização de sistemas de semiclimatização de ambiente, em galpões para frangos de corte, no sudoeste de Goiás. 2002. 148f. Tese (Doutorado em Engenharia Agrícola) - Universidade Federal de Viçosa, Viçosa, MG.

OLIVEIRA, J.E.; SAKOMURAN, K.; FIGUEIREDO A.N. et al. Efeito do isolamento térmico de telhado sobre o desempenho de frangos de corte alojados em diferentes densidades. Revista Brasileira de Zootecnia, v.29, n.5, p.1427-1434, 2000.

OLIVEIRA, R.F.M.; DONZELE, J.L.; ABREU, M.L.T. et al. Efeitos da temperatura e da umidade relativa sobre o desempenho e o rendimento de cortes nobres de frangos de corte de 1 a 49 dias de idade. Revista Brasileira de Zootecnia, v.35, n.3, p.797-803, 2006.

OLIVEIRA, M.C.; GOULART, R.B.; SILVA, J.C.N. Efeito de duas densidades e dois tipos de cama sobre a umidade da cama e a incidência de lesões na carcaça de frango de corte. Ciência Animal Brasileira, v.3, n.2, p.7-12, 2002.

SEVEGNANI, K.B.; MACARI, M.; NÄÄS, I.A. et al. Variação das perdas de calor sensível e latente em frangos de corte submetidos à ventilação artificial. In: CONGRESSO BRASILEIRO DE ENGENHARIA AGRÍCOLA, 30., 2001. Anais... Foz do Iguaçu: CONBEA, 2001. (CD-ROM).

SOLIMAN, E.S.; TAHA, E.G.; SOBIEH, M.A.A. et al. The influence of ambient environmental conditions on the survival of salmonella enteric serovar typhimurium in poultry litter. International Journal of Poultry Science, v.8, n.9, p.848-852, 2009.

STATISTICAL ANALYSIS SYSTEM - SAS. System for Microsoft Windows: release 9.1. Cary, 2002-2003. (CD-ROM).

TAVARES, F.; ABREU, P.G.; ABREU, V.M.N. et al. Temperatura da cama como condição de conforto e bem-estar das aves. Revista Brasileira de Ciência Avícola, p.213, supl. 10, 2008.

TEIXEIRA, V.H. Estudo dos índices de conforto em duas instalações de frango de corte para as regiões de Viçosa e Visconde do Rio Branco, MG. 1983. 62f. Dissertação (Mestrado em Zootecnia), Universidade Federal de Viçosa, Viçosa, MG.

TINÔCO, I.F.F.; MATOS, M.L.; VIGODERIS, R.B. et al. Influência de dois sistemas de ventilação sobre a UR em galpões de frango de corte. In: CONGRESSO BRASILEIRO DE ENGENHARIA AGRÍCOLA, 30., 2001. Anais... Foz do Iguaçu: CONBEA, 2001. (CD-ROM).

XAVIER, L.H. Modelos univariado e multivariado para análise de medidas repetidas e verificação da acurácia do modelo univariado por meio de simulação. 91f. 2000. Dissertação (Mestrado em Agronomia) - Escola Superior de Agricultura "Luiz de Queiroz", Piracicaba. 